\title{
PEMAKNAAN MAHASISWA TERHADAP NARASI KONFLIK BERAGAMA
}

\author{
Silvia Rahmelia \\ Institut Agama Kristen Negeri Palangka Raya \\ silviarahmelia@gmail.com
}

\begin{abstract}
Abstrak
Konflik beragama di Indonesia menunjukkan bahwa potensi terjadinya konflik bisa berakar dari beberapa faktor seperti politik, ekonomi dan kultur pendidikan, sehingga penting untuk memahami bagaimana kita melihat konflik dengan cara berbeda. Telaah ini dilakukan dengan menggunakan teknik pengumpulan data primer berupa kuesioner terbuka dan tertutup kepada mahasiswa Institut Agama Kristen Negeri (IAKN) Palangka Raya dari berbagai program studi. Berdasarkan data yang didapat, pemaknaan mahasiswa mengenai konflik beragama menggambarkan ralita yang terjadi bahwa 1) konflik beragama banyak berawal dari tidak adanya toleransi antar umat beragama; 2) konflik beragama bisa berawal dari sikap eksklusif/fanatik seseorang atau sekelompok agama tertentu yang mengarah pada pemahaman truth claim; 3) konflik beragama dapat memicu terjadinya radikalisme dan terorisme. Pemahaman dan pemaknaan mahasiswa IAKN Palangka Raya terhadap konflik beragama juga dilatar belakangi oleh berbagai informasi yang mereka dapatkan. Diharapkan dengan pemahaman dan pemaknaan yang tergambar dalam diri mahasiswa dapat menjadi titik tolak pengelolaan kemajemukan beragama yang lebih baik di masa mendatang terutama dalam sektor pendidikan
\end{abstract}

Kata kunci: Agama, Indonesia, Konflik, Mahasiswa

\begin{abstract}
Religious conflict in Indonesia shows that the potential for conflict can stem from several factors such as politics, economy and educational culture, so it is important to understand how we view conflict differently. This study was conducted using primary data collection techniques in the form of open and closed questionnaires to students of Institut Agama Kristen Negeri Palangka Raya (IAKN) from various study programs. Based on the data obtained, the students' interpretation of religious conflicts illustrates the problems that occur that 1) many religious conflicts originate from the intolerance of religious communities; 2) religious conflict can originate from the exclusive / fanatical attitude of a person or group of certain religions which leads to an understanding of truth claims; 3) religious conflicts can trigger radicalism and terrorism. The understanding and meaning of IAKN Palangka Raya students towards religious conflicts is also motivated by the various information they get. It is hoped that the understanding and meaning that is reflected in students can become a starting point for better management of religious plurality in the future, especially in the education sector.
\end{abstract}

Keywords: Conflict, Indonesia, Religious, Student

\section{PENDAHULUAN}

Indonesia sebagai negara majemuk dengan masyarakat yang multi agama kerapkali menimbulkan konflik. Meski tidak selalu disebabkan oleh satu atau dua agama tertentu, namun beberapa peristiwa konflik di Indonesia menyeret mayoritas agama tertentu ke pusaran determinan konflik. Agama di satu sisi membebaskan pemeluknya untuk dapat bergaul dengan orang lain yang berbeda tanpa ada tekanan atau beban tertentu (Dewantara \&
Nurgiansah, 2021). Namun di sisi lain agama juga memperbudak, terlihat dari sikap ingin menang sendiri dan merasa unggul dari agama lain. Sikap ini cenderung menempatkan pemeluk agama lain sebagai masyarakat yang termarginalkan. Realitas menunjukkan bahwa ketegangan yang terjadi di antara umat beragama justru berkaitan erat dengan faktor-faktor yang berada di luar lingkup agama itu sendiri (Effendy, 2001). Menjadikan negara dengan berjuta-juta penduduk bebas dari konflik 
seperti sebuah fatamorgana. Sebab masingmasing orang dalam suatu kelompok memiliki kepentingan yang berbeda-beda dan hal ini secara langsung maupun tidak langsung akan berpengaruh terhadap implementasi suatu kebijakan. Bahkan ketika ada persoalan personal sekalipun, bisa merembet menjadi persoalan kelompok. Karena sifat rela berkorban dan "membela" kebenaran dalam suatu ajaran yang diyakini menjadi salah satu ciri khas dari pemeluk agama di Indonesia. Munculnya konflik keagamaan di Indonesia beberapa dekade terakhir menunjukkan bahwa potensi terjadinya konflik bisa dari beberapa faktor seperti politik, ekonomi, kultur dan sebagainya, sehingga penting untuk memahami bagaimana kita melihat konflik dengan cara berbeda. Sebagaimana dikatakan bahwa konflik bukan sebagai ancaman, melainkan sebagai komunikasi untuk membangun hubungan baik untuk saling memberi ruang kebebasan dan saling menghargai (Roswantoro, 2018).

Masyarakat tidak seluruhnya mengetahui penyebab dan solusi dari konflik beragama ini. Beberapa faktor disebabkan oleh penyebaran informasi dari media yang kurang dapat diakses secara merata. Mengingat faktor geografis Indonesia dan di sisi lain banyak masyarakat yang cenderung kurang peduli dan kurang teredukasi sehingga tidak mampu berpikir terlalu jauh tentang peristiwa-peristiwa yang terjadi di Indonesia. Di sisi lain, adanya konflik disebabkan oleh perbedaan suku, ras, agama, budaya dan bahkan bahasa yang pada akhirnya mengindikasikan ketidakberhasilan lembaga pendidikan dalam memupuk rasa kebersamaan dan toleransi. Padahal toleransi beragama pada hakikatnya berdampak terhadap kebermaknaan hidup generasi muda, dalam hal ini siswa/mahasiswa. sebagaimana penelitian yang dilakukan Supardi dan Rahmelia yang menyatakan bahwa tingginya kebermaknaan hidup ditandai juga dengan tingginya toleransi beragama (Supardi \& Silvia, 2020)

Komisi untuk Orang Hilang dan Korban Tindak Kekerasan (Kontras) menyebutkan sepanjang 2019 ada 70 peristiwa pembatasan terhadap kebebasan beragama, berkeyakinan, dan beribadah, dengan mayoritas pelanggaran adalah pelarangan dan persekusi. (Ridwan, 2020). Kemudian dari 27 kasus yang diteliti selama kurun waktu 2017-2019 dapat dipetakan bahwa satu kasus konflik terkait isu terorisme, 14 kasus konflik terkait isu komunal (antaragama), dan 12 kasus konflik terkait isu sektarian (intraagama). Itu artinya konflik agama berjenis komunal paling banyak terjadi. Kemudian diikuti dengan jenis sektarian dan terorisme (Khalwani, 2019).

Berbicara mengenai konflik beragama, isu paling sensitif yang terkait adalah tentang terorisme dan radikalisme. Dua kata kunci ini bisa menafsirkan banyak hal tentang latar belakang maupun dampak dari berbagai konflik beragama di Indonesia. Bahkan dalam beberapa dekade terakhir pemerintah turut menyoroti permasalahan terorisme dan radikalisme hingga munculnya Badan Nasional Penaggulangan Terorisme (BNPT). Belakangan pemerintah menyadari bahwa tidak hanya penanggulangan yang diperlukan dalam menangani terorisme dan radikalisme, namun penyimpangan ideologi Pancasila sebagai faktor penyebab yang perlu diantisipasi. Maka dari itu dibentuklah Badan Pembinaan Ideologi Pancasila (BPIP) sebagai unit khusus di bawah Presiden guna memperkokoh ideologi Pancasila di masyarakat (Nurgiansah, 2021). Belakangan yang terjadi di negara Indonesia banyak pihak melegitimasi kekerasan atas nama Tuhan, padahal kekerasan dari perspektif manapun tidak dibenarkan terlebih lagi dari sudut pandang agama (Yunus et al., 
2014). Sejalan dengan pemahaman bahwa tidak ada martabat suatu agama atau suatu kepercayaan keagamaan yang bisa ditinggikan dengan pemaksaan kehendak dan kekerasan fisik. Sacks mengartikulasikan hal ini dengan pernyataannya, "No religion won the admiration of the world by its capacity to inflict suffering on its enemies." (Tidak ada agama yang memenangkan kehormatan dunia dengan kemampuannya menimpakan penderitaan pada musuh-musuhnya) (Sack, 2015)

Hal lain yang juga disoroti perihal konflik beragama adalah personal insecurities dari pelaku yang terlibat. Personal insecurities maksudnya adalah perasaan tidak nyaman dari seorang pemeluk agama tertentu terhadap keberadaan agama lain. Individu seperti ini cenderung menyoroti kesalahan dan perbedaan dari ritual atau ajaran agama tertentu lalu membandingkan dengan agamanya sendiri. Sependapat dengan hal ini, faktor penyebab konflik antar umat beragama diantaranya adalah klaim kebenaran (truth claim) dan doktrin jihad (Yunus et al., 2014). Dari perilaku tersebut terkadang muncul truth claim, dimana individu tersebut merasa bahwa kebenaran hanya berasal dari agama yang dianutnya. Ketidaknyamanan seorang individu saat berada di tengah agama yang berbeda-beda juga dapat menyebabkan orang cenderung menyalahkan dan mudah terseret dalam arus konflik.

Di lingkungan pendidikan, Pendidikan Agama yang telah diamanatkan konstitusi melalui Undang-undang Sistem Pendidikan Nasional Nomor 20 Tahun 2003 ditengarai mengembangkan prasangka dan mengeskalasi ketegangan antar kelompok melalui konstitusi yang mengkotakkotakkan penyampaian pendidikan agama, isi kurikulum yang etnosentris, dan dinamika relasi sosial antar sekolah yang segregatif (Khisbiyah, 2000). Namun demikian semakin tahun, pendidikan agama baik di lingkungan persekolahan maupun pendidikan tinggi telah banyak meninggalkan jejak moderasi beragama. Di lingkungan pendidikan tinggi, mahasiswa selaku agen perubahan sekaligus modal sosial Indonesia dalam menjaga kemajemukan dan moderasi beragama di kemudian hari, tentunya menjadi sebuah kewajiban untuk turut menjaga Indonesia dari potensi konflik beragama yang berkepanjangan.

Mahasiswa perlu sadar dan terdidik tentang makna toleransi di tengah kehidupan yang beragam suku dan agama. Disamping itu mahasiswa perlu mengenal penyebab terjadinya terorisme sebagai tindakan merugikan dari sebuah konflik beragama. Tidak lain bahwa penyebab itu dapat berasal dari intoleransi yang mengarah pada radikalisme dan ekstrimisme sehingga berujung pada tindakan teror yang mengancam banyak orang. Awareness dan curiosity perlu ada dalam diri mahasiswa agar tidak termakan pemberitaan yang keliru. Sebab dari ketidaktahuan ditambah dengan pemberitaan yang kurang kredibel, mahasiswa dapat terseret pemahaman yang keliru tentang makna kehidupan beragama. Hal ini yang perlu diantisipasi baik melalui pembelajaran Pancasila di perguruan tinggi maupun pola asuh keluarga dan lingkungan pergaulan.

Institut Agama Kristen Negeri (IAKN) Palangka Raya sebagai salah satu Perguruan Tinggi Keagamaan Negeri di Indonesia berperan mencegah terjadinya konflik beragama di Indonesia.

Terlebih dengan lingkungan masyarakat Kalimantan Tengah yang beragam. Corak Kristen menjadi misi yang perlu ditanamkan pada setiap mahasiswa agar memiliki karakter Kristiani yang sejalan dengan ajaran Kristus dalam Alkitab. Hal ini juga senada dengan persepsi tentang moderasi beragama yang perlu 
ditanamkan juga dalam pembelajaran Pendidikan Kewarganegaraan. Sebagaimana dikatakan Rahmelia dan Apandie bahwa pada akhirnya moderasi beragama dalam Pendidikan Kewarganegaraan sangat perlu sekali untuk diimplementasikan dengan upaya untuk menanamkan sikap toleran dalam bingkai pendidikan multikultural. "In the end, the understanding of religious moderation in citizenship education needs to be implanted along with efforts to fostering tolerant attitude in a multicultural education and tolerance education" (Rahmelia \& Apandie, 2020)

Di sisi lain IAKN Palangka Raya perlu menyemai benih moderasi beragama di tengah kehidupan masyarakat Indonesia khususnya Kalimantan Tengah yang beragam. Maka dari itu perlu ada upaya yang seimbang dari lembaga agar mampu menghasilkan lulusan yang memiliki karakter Kristiani yang sejalan dengan visi moderasi beragama demi mendukung kehidupan masyarakat majemuk.

Pemaknaan mahasiswa terhadap
narasi konflik beragama dapat dikategorikan ke dalam 1) pemaknaan intoleransi sebagai penyebab konflik beragama; 2) pemaknaan eksklusivisme /fanatisme/truth claim sebagai penyebab konflik beragama; 3) pemaknaan konflik beragama sebagai penyebab terorisme dan radikalisme. Kemudian dari berbagai pandangan dan pemaknaan tersebut, dapat diteliti juga tanggapan mahasiswa terhadap kelompok agama tertentu diluar agama mereka kaitannya dengan sikap toleransi dan tindakan afektif sebagai bagian dari masyarakat Indonesia yang majemuk.

Berdasarkan latar belakang tersebut, penelitian ini bertujuan untuk mengetahui pemaknaan mahasiswa Institut Agama Kristen Negeri Palangka Raya tentang konflik beragama yang terjadi di Indonesia. Adapun mini research ini diperlukan sebagai titik awal untuk menelaah lebih jauh pandangan kelompok agama tertentu terhadap konflik beragama di Indonesia. Bagaimana hal tersebut dapat berpengaruh terhadap sikap toleran atau pandangan secara umum sebagai masyarakat yang multikultural.

\section{METODE PENELITIAN}

Telaah ini dilakukan dengan menggunakan teknik pengumpulan data primer berupa kuesioner terbuka dan tertutup kepada 20 orang mahasiswa dari berbagai program studi, ditambah dengan wawancara terstruktur sebagai data sekunder guna melengkapi jawaban dari kuesioner. Pemilihan responden/informan dalam telaah ini ditentukan berdasarkan teknik purposive sampling yaitu kepada mahasiswa dari berbagai semester /tingkatan yang telah mengontrak mata kuliah Pendidikan Pancasila dan Kewarganegaraan. Pemilihan ini dilakukan agar data yang dihasilkan lebih bervariasi dan terkendali di bawah pengawasan dosen pengampu Pendidikan Pancasila dan Kewarganegaraan.

Terkait pengumpulan data selama masa pandemi, digunakan media pengumpulan data berupa google form dan aplikasi percakapan WhatsApp. Kemudian analisis data yang dilakukan adalah analisis interaktif, yaitu reduksi data dari mulai proses pemilihan, pemusatan perhatian dan penyederhanaan. Sajian data yang dipilih dengan bentuk narasi deskriptif dengan pengambilan kesimpulan berdasarkan rangkuman dan olahan data yang diperoleh dari responden/informan.

Penentuan mini research ini juga didasari oleh pembatasan masalah yaitu 1) kelompok responden/informan dari agama tertentu; 2) pemaknaan narasi konflik beragama yang terjadi secara khusus di Indonesia rentang tahun 2015 s.d 2020; 3) representasi pertanyaan dari pemaknaan narasi konflik beragama berkisar antara konsep terorisme, radikalisme dan truth 
claim sebagai kata kunci dari penyebab terjadinya konflik beragama. Dengan demikian faktor-faktor yang ditimbulkan dari pemaknaan mahasiswa terhadap narasi konflik beragama hanya menjangkau dimensi-dimensi tertentu yang khusus dan tidak dapat ditarik secara bebas menjadi sebuah proposisi yang umum.

\section{HASIL PENELITIAN DAN PEMBAHASAN Hasil Penelitian}

\section{Pemaknaan Intoleransi sebagai} Penyebab Konflik Beragama

Awal mula konflik pada dasarnya disebabkan oleh perbedaan nilai yang dianut. Nilai dapat menjadi pemicu ketika terjadi interaksi di masyarakat. Misalnya saat terdapat ketidaksesuaian antara nilai yang dianut dengan nilai yang menjadi realitas di masyarakat. Ketidaksesuaian ini awalnya tidak berarti apa-apa, hingga pada akhirnya semakin banyak orang yang tidak sesuai dan secara bersama-sama membuat sebuah prasangka.

Awal mula konflik sebagaimana digambarkan di bawah ini, selaiin disebabkan oleh nilai-nilai yang berbeda juga disebabkan oleh kebutuhan dasar yang tidak ditemui dan sumber-sumber terbatas waktu (Fiadjoe, 2004)

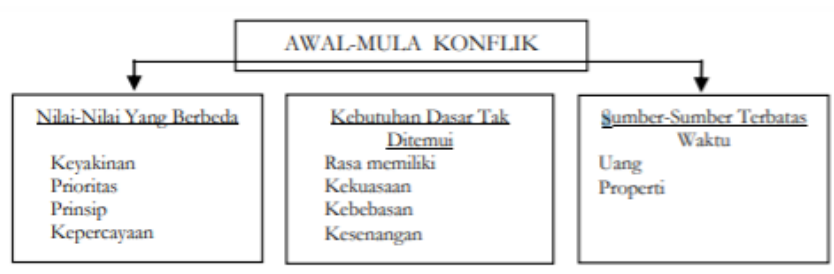

Gambar 1. Awal Mula Konflik

Konflik beragama di Indonesia banyak diawali oleh sikap intoleransi atau tidak adanya tenggang rasa terhadap perbedaan nilai. Padahal di negara majemuk seperti Indonesia pluralisme agama adalah sebuah natur. Pemaknaan mahasiswa terhadap pluralisme agama disimpulkan dalam tiga kategori, yaitu
1. Kategori pertama sebagai sikap menerima (acceptance), kelompok ini tidak berhubungan langsung dengan pemahaman keberagamaan. Mereka bersikap netral dan selalu bersikap positif terhadap ide atau pembaharuan.

2. Kategori kedua yaitu sikap menolak (resistance), hal ini ketika menanggapi konsep pluralitas atau plurlisme agama masih terkait dengan dengan tingkat pemahaman keberagamaan mereka. Alasan penolakan cenderung mengkritik tentang konsep relativisme kebenaran dalam pluralisme agama

3. Kategori ketiga yaitu sikap yang raguragu. Mahasiswa yang mempunyai sikap ini tidak mempunyai makna apapun. Bagi mereka, pluralitas agama tidak ada maknanya karena tidak berpengaruh terhadap kehidupan sosial mereka (Zamakhsari, 2017)

Berdasarkan data yang didapat, pemaknaan mahasiswa mengenai konflik beragama yang berawal dari tidak adanya toleransi ialah $66,7 \%$ menjawab sangat setuju, 26,7\% menjawab setuju, 6,7\% menjawab ragu-ragu. Hal ini menandakan bahwa banyak dari mahasiswa yang memahami bahwa konflik beragama banyak berawal dari tidak adanya toleransi antar umat beragama.

Realita di lapangan juga mengarah kepada hasil yang sama. Beberapa konflik beragama di Indonesia dipicu oleh konflik horizontal bernuansa vertikal. Peristiwa penolakan hingga pembakaran rumah ibadah. Tidak adanya sikap tenggang rasa, lapang dada dan saling menghormati antar pemeluk agama di Indonesia.

Namun demikian mahasiswa menyadari bahwa konflik beragama di Indonesia dapat diatasi dengan toleransi beragama yang kuat. Asumsi ini dibuktikan dengan data yang didapat yaitu $86,7 \%$ 
menjawab sangat setuju, 6,7\% menjawab setuju, 6,7\% menjawab ragu-ragu.

Perasaan empati terhadap sebuah paham atau pandangan yang ada dalam suatu agama tertentu memberikan orang atau kelompok pemeluk agama lain belajar menghormati suatu pendirian. Sebab sebuah kewajaran dapat terjadi di manapun, dalam setiap hubungan interaksi sosial masyarakat terutama di negara Indonesia yang majemuk. Dengan demikian intoleransi dapat dicegah jika masing-masing pemeluk agama menyadari kewajaran itu.

\section{Pembahasan}

Pemaknaan Eksklusivisme / Fanatisme / Truth Claim sebagai Penyebab Konflik Beragama

Ajaran Kristen mengedepankan pendekatan eksklusivisme yang menyatakan bahwa agama Kristen adalah satu-satunya jalan keselamatan melalui Yesus Kristus. Namun demikian, jika ditelaah secara mendalam hampir semua agama memiliki ajaran itu. Semua agama ingin dianggap benar dan mengklaim diri sebagai umat yang diselamatkan Tuhan. Eksklusivisme mengarah pada pemisahan diri dari kerumunan. Pada narasi konflik beragama, eksklusivisme dalam hal ini adalah kecenderungan untuk memisahkan diri dari masyarakat dan memisahkan interaksi sosial menjadi sekat-sekat tertentu sehingga hanya mengedepankan interaksi bersama golongan yang seiman.

Agama tidak hanya sebagai ajaran yang dogmatis bagi para pemeluknya. Agama lebih dari pada itu disusun dengan banyak penafsiran yang mengandung klaim kebenaran (truth claim) yang mau tidak mau secara masif dijdikan doktrin dan mesti disebarluaskan. Maka dari itu banyak dari konflik beragama menyiarkan ungkapan yang tidak utuh dari pemeluk agama tertentu. Salah satu hal yang sering menimbulkan konflik dan ketegangan sosial adalah soal agama, karena ada umat agama yang mengklaim dirinya paling benar, yang lainnya sesat. Klaim ini kemudian melahirkan keyakinan yang biasa disebut dengan "doctrine of salvation" (doktrin keselamatan), bahwa keselamatan (surga) adalah hak para pengikut agama tertentu saja, sedangkan yang lainnya celaka dan akan masuk neraka (Thoha, 2005).

Mahasiswa yang memiliki pemahaman bahwa konflik beragama bisa berawal dari sikap eksklusif/fanatik seseorang atau sekelompok agama tertentu ialah 46,7\% menjawab sangat setuju, 46,7\% menjawab setuju, 6,7\% menjawab ragu-ragu. Kemudian mengenai eksklusivisme / fanatisme / truth claim, kebanyakan dari mereka hanya mengikuti mitos klaim kebenaran yang secara singkatnya berupaya menyampaikan pesan Tuhan kepada manusia. Pada dasarnya agama memerankan dua fungsi, yaitu menjelaskan suatu cakrawala pandangan tentang dunia yang tidak terjangkau oleh manusia (beyond) yang dapat melahirkan deprivasi dan frustasi yang bermakna. Kemudian agama sebagai sarana ritual yang memungkinkan hubungan manusia dengan hal yang diluar jangkauannya (Lubis, 2017). Agama juga bersifat ambigu dapat membebaskan tapi sekaligus memperbudak (Putrani, 2016).

Berdasarkan data yang didapat, mahasiswa memaknai bahwa konflik beragama juga disebabkan oleh sikap eksklusif dan fanatik yang membawa pemahaman truth claim. Mahasiswa yang memiliki pemahaman bahwa konflik beragama muncul karena sekelompok orang yang berusaha menafsirkan kembali ajaran agama menurut pemahamannya masing-masing ialah 46,7\% menjawab sangat setuju, $40 \%$ menjawab setuju, $13,3 \%$ menjawab ragu-ragu.

Meski tidak selamanya eksklusivisme mengarah pada keterasingan, bahayanya sikap eksklusif ini dekat dengan fanatisme 
yang dapat mengakibatkan seseorang terlalu kuat berpegang pada sebuah ajaran doktrin yang diyakini. Sikap yang terlalu kuat ini pada akhirnya tidak mampu membiarkan pemeluk agama untuk memiliki sikap toleran. Tentunya hal ini berdampak pula terhadap truth claim yang menyebabkan paham pluralitas menjadi semakin tenggelam. Sedangkan paham pluralitas ini adalah salah satu modal untuk menjaga kerukunan umat beragama di Indonesia. Paham pluralitas perlu ditanamkan juga secara dini kepada pelajar dan mahasiswa guna menyadarkan mereka terhadap lingkungan Indonesia yang majemuk. Paham pluralitas perlu disosialisasikan sedini mungkin kepada mahasiswa, agar mereka dapat merespon secepatnya terhadap kondisi yang terjadi di sekitar lingkungan mereka (Amaliyah, 2017).

\section{Pemaknaan Konflik Beragama sebagai Penyebab Terorisme dan Radikalisme}

Konflik beragama yang berawal dari sikap intoleran dan eksklusivisme dari seorang atau sekelompok pemeluk agama tertentu pada akhirnya dapat memantik perilaku teror dan radikal. Bisa dianggap bahwa sikap intoleran, eksklusivisme/fanatisme dan paham truth claim membuat seseorang menjadi berpikiran terlalu keras terhadap perubahan yang mendasar dan cenderung ekstrim. Misi pembaharuan yang dibawa suatu kaum radikal pada akhirnya bisa berdampak pada perilaku teror.

Peristiwa teror tidak sekali dua kali terjadi di Indonesia. Telah banyak korban jiwa yang diakibatkan terorisme bahkan hingga menjadi sorotan dunia Internasional. Tidak dapat dipungkiri perilaku teror ini memang tidak hanya terjadi di Indonesia. Belahan dunia lain mengalami hal yang sama bahkan bisa jadi dampaknya lebih parah. Kemudian mengenai radikalisme dan terorisme yang disebabkan oleh konflik agama yang berkepanjangan telah menumbuhkan kebencian yang mendalam bagi hubungan umat beragama.

Terorisme dan radikalisme pada hakikatnya tidak hanya didasari oleh konflik beragama, namun juga merupakan dampak dari sebuah ajaran agama yang salah. Mengenai hal ini, pemaknaan mahasiswa terhadap pemahaman bahwa terorisme adalah buah ajaran yang salah dari suatu agama tertentu ialah 46,7\% menjawab sangat setuju, 26,7\% menjawab setuju, 6,7\% menjawab ragu-ragu, 6,7\% menjawab tidak setuju dan $13,3 \%$ sangat tidak setuju.

Hal ini menandakan bahwa mahasiswa menyadari penyebab dari ajaran agama yang salah dapat menyebabkan peristiwa teror yang mengancam nyawa orang banyak. Kekeliruan dalam memahami ajaran agama dapat dikatakan sebagai human error, sehingga tidak bisa disalahkan tools-nya atau agamanya.

Kemudian mahasiswa yang memiliki pemahaman bahwa konflik beragama di Indonesia disebabkan oleh paham radikalisme ialah $60 \%$ menjawab sangat setuju, 26,7\% menjawab setuju, 13,3\% menjawab ragu-ragu. Paham radikalisme yang berbahaya dan berujung pada terorisme adalah paham radikalis ekstrimis yang berawal dari sikap intoleran terhadap suatu kelompok agama tertentu. Ujungnya adalah konflik agama memiliki kaitan erat terhadap tumbuhnya sikap radikal, terutama di kalangan mahasiswa. Tidak menutup kemungkinan berbagai pemberitaan konflik beragama dapat berujung pada kebencian terhadap kelompok agama tertentu dan mengakibatkan sikap radikal-ekstrimis. Data tersebut berkaitan erat juga dengan pemahaman mahasiswa bahwa paham radikalisme sangat berbahaya bagi kerukunan umat beragama di Indonesia. $60 \%$ menjawab sangat setuju, 26,7\% 
menjawan setuju, 6,7\% menjawab raguragu, 6,7\% menjawab tidak setuju.

Konflik beragama yang berujung pada kekerasan dengan adanya terorisme, menandakan bahwa kekerasan dapat digunakan untuk menyatakan ketidaksetujuan oleh kelompok agama yang dominan terhadap kelompok agama yang rentan (Putrani, 2016). Dampaknya konflik yang berkecamuk dapat membuat masyarakat semakin tidak mampu mengelola kemajemukan dan kerukunan umat beragama yang telah ada. Meskipun terdapat kemungkinan setelah konflik itu akan muncul titik terang yang membawa kedamaian satu sama lain, namun setelah konflik berkecamuk tidak jarang masyarakat cenderung ekstrem dalam mengelola kemajemukan (Mahyuddin et al., 2020). Berbagai penelitian menunjukkan bahwa hubungan antar elemen masyarakat yang berbeda agama, mulai tersekat dalam hal interaksi dan cenderung menutup diri, ketiadaan kerja sama serta merebaknya gesekan kelompok (Lindawati, 2016; Manuputty, 2014).

Pemahaman dan pemaknaan mahasiswa terhadap konflik beragama juga dilatar belakangi oleh berbagai informasi yang mereka dapatkan. Berdasarkan data yang didapat, mahasiswa mengetahui konflik beragama yang ada di Indonesia yaitu seputar intoleransi, perselisihan agama di Aceh, penistaan agama, truth claim, gerakan fanatik/radikal, pembakaran tempat ibadah, ujaran kebencian.

Pada penghujung tahun lalu, Kemenag meluncurkan aplikasi Sistem Peringatan dan Respons Dini Konflik Keagamaan guna melacak potensi perselisihan beragama di dalam masyarakat. Aplikasi ini akan mengumpulkan informasi tentang gelagat konflik, seperti hoaks, isu-isu sektarian, aktivitas keagamaan tertentu, dan lain-lain. (Permana, 2020). Hal ini tentunya akan membantu masyarakat termasuk kalangan mahasiswa dalam berperan meminimalisir konflik beragama yang terjadi.

Diharapkan dengan pemahaman dan pemaknaan yang tergambar dalam diri mahasiswa ini dapat menjadi titik terang dari pengelolaan kemajemukan beragama yang lebih baik di masa mendatang. Tentunya dengan dukungan dari Pemerintah dan lingkungan sekitar yang berperan baik, bukan tidak mungkin konflik beragama di Indonesia dari waktu ke waktu dapat semakin mereda.

\section{KESIMPULAN}

Konflik beragama di Indonesia banyak diawali oleh sikap intoleransi atau tidak adanya tenggang rasa terhadap perbedaan nilai. Padahal di negara majemuk seperti Indonesia pluralisme agama adalah sebuah natur. Di lingkungan pendidikan, mahasiswa perlu sadar dan terdidik tentang makna toleransi di tengah kehidupan yang beragam suku dan agama. Disamping itu mahasiswa perlu mengenal penyebab terjadinya terorisme sebagai tindakan merugikan dari sebuah konflik beragama.

Berdasarkan data yang didapat, pemaknaan mahasiswa mengenai konflik beragama yang berawal dari tidak adanya toleransi ialah $66,7 \%$ menjawab sangat setuju. Namun demikian mahasiswa menyadari bahwa konflik beragama di Indonesia dapat diatasi dengan toleransi beragama yang kuat. Asumsi ini dibuktikan dengan data yang didapat yaitu $86,7 \%$ menjawab sangat setuju.

Kemudian mengenai eksklusivisme / fanatisme / truth claim, kebanyakan dari mereka hanya mengikuti mitos klaim kebenaran yang secara singkatnya berupaya menyampaikan pesan Tuhan kepada manusia. Mahasiswa yang memiliki pemahaman bahwa konflik beragama bisa berawal dari sikap eksklusif / fanatik seseorang atau sekelompok agama tertentu ialah 46,7\% menjawab sangat setuju, Meski tidak selamanya eksklusivisme mengarah 
pada keterasingan, bahayanya sikap eksklusif ini dekat dengan fanatisme yang dapat mengakibatkan seseorang terlalu kuat berpegang pada sebuah ajaran doktrin yang diyakini. Terorisme dan radikalisme pada hakikatnya tidak hanya didasari oleh konflik beragama, namun juga merupakan dampak dari sebuah ajaran agama yang salah. Mengenai hal ini, pemaknaan mahasiswa terhadap pemahaman bahwa terorisme adalah buah ajaran yang salah dari suatu agama tertentu ialah 46,7\% menjawab sangat setuju, Kemudian mahasiswa yang memiliki pemahaman bahwa konflik beragama di Indonesia disebabkan oleh paham radikalisme ialah $60 \%$ menjawab sangat setuju. Data tersebut berkaitan erat juga dengan pemahaman mahasiswa bahwa paham radikalisme sangat berbahaya bagi kerukunan umat beragama di Indonesia. $60 \%$ menjawab sangat setuju, Pemahaman dan pemaknaan mahasiswa terhadap konflik beragama juga dilatar belakangi oleh berbagai informasi yang mereka dapatkan. Berdasarkan data yang didapat, mahasiswa mengetahui konflik beragama yang ada di Indonesia yaitu seputar intoleransi, perselisihan agama di Aceh, penistaan agama, truth claim, gerakan fanatik/radikal, pembakaran tempat ibadah, ujaran kebencian.

\section{DAFTAR PUSTAKA}

Amaliyah, E. I. (2017). Makna Pluralitas Agama di Kalangan Mahasiswa STAIN Kudus dan Implementasinya Melalui Mata Kuliah Perbandingan Agama. Wawasan: Jurnal Ilmiah Agama Dan Sosial Budaya, 2(1), 1-10. https://doi.org/10.15575/jw.v2i1.587

Dewantara, J. A., \& Nurgiansah, T. H. (2021). Building Tolerance Attitudes Of PPKN Students Through Multicultural Education Courses. Jurnal Etika Demokrasi, 6(1), 103-115.

Fiadjoe, A. (2004). Alternative Dispute Resolution: A Developing World Perspective. Cavendish Publishing Limited.

Lindawati, D. S. (2016). Konflik Ambon: Kajian Terhadap Beberapa Akar Permasalahan Dan Solusinya. Jurnal Politica Dinamika Masalah Politik Dalam Negeri Dan Hubungan Internasional, 2(2).

Lubis, R. (2017). Sosiologi Agama (Memahami Perkembangan Agama dalam Interaksi Sosial) (I. Syaukani (ed.)). Kencana.

Mahyuddin, Pikahulan, R. M., \& Fajar, M. (2020). Peran Strategis IAIN Ambon dan IAKN Ambon dalam Merawat Toleransi Sosial dan Moderasi Beragama di Ambon Maluku. KURIOSITAS: Media Komunikasi Sosial, 13(1), 103-124.

Manuputty, J. (2014). Carita Orang Basudara: Kisah-Kisah Perdamaian Dari Maluku. Pusat Studi Agama dan Demokrasi Yayasan Paramadina Jakarta.

Nurgiansah, T. H. (2021). Pendidikan Pancasila. In Solok: CV Mitra Cendekia Media.

Permana, F. E. (2020). Kemenag Waspadai Potensi Konflik Beragama di Tengah Pandemi. Republika.Com.

Putrani, B. D. (2016). Perempuan, Konflik, dan Rekonsiliasi,. Gunung Mulia.

Rahmelia, S., \& Apandie, C. (2020). Fostering Religious Moderation's Perception in the 4.0 Era: Citizenship Education Challenge. 418(Acec 2019), 518-523. https://doi.org/10.2991/assehr.k.200320.098

Supardi, J. S., \& Silvia, R. (2020). Meaningful Life and the Degree of Tolerance in Faith-Based High Schools in Palangkaraya. Dialog, 43(1), 49-58.

Thoha, A. M. (2005). Tren Pluralisme Agama, Tinjauan Kritis. Perspektif.

Yunus, F. M., Ushuluddin, F., Islam, U., \& Uin, N. (2014). Substantia, Volume 16 Nomor 2, Okotber 
2014 http://substantiajurnal.org. 16, 217-228.

Zamakhsari, A. (2017). Pengembangan Pluralisme Agama di Kalangan Mahasiswa. Jurnal Indo Islamika, 7(1), 65-84. 